\title{
PENGARUH PRICE DISCOUNT DAN IN-STORE DISPLAY TERHADAP IMPULSE BUYING PADA LABELLO STORE MEDAN
}

\author{
Desma Erica Maryati ${ }^{1}$ Erveni $^{2}$ \\ ${ }^{1,2}$ STIE Eka Prasetya, Medan, Indonesia \\ ${ }^{1}$ desmaerica79@gmail.com, ${ }^{2}$ ervenihuang@ yahoo.com
}

\begin{abstract}
The purpose of this study is to determine the effect of Price Discount on Impulse Buying at Labello Store Medan, determine the effect of In-Store Display on Impulse Buying at Labello Store Medan, determine the effect of Price Discount and In-Store Display on Impulse Buying at Labello Store Medan. The research methodology used descriptive quantitative method, the unit of analysis in this study is Labello Store Medan and its observation unit are customers of Labello Store Medan as many as 980 respondents. The technique of determining the number of samples used in this study was the Slovin formula and amounted to 91 respondents. The research method used is by data collection techniques through library research and field research conducted systematically based on research objectives. The analytical method used to solve problems and prove hypothesis is descriptive analysis, regression analysis. The test results of the coefficient of determination (R2) indicate that of the Impulse Buying variable is influenced by Price Discount and In-Store Display variables, while the remaining is explained by the influence of other factors variables outside the model such as fashion involvement, positive emotion, store image and social media.
\end{abstract}

Keywords : Price Discount, In-Store Display, Impulse Buying

\begin{abstract}
ABSTRAK
Penelitian ini bertujuan untuk mengetahui pengaruh Price Discount terhadap Impulse Buying pada Labello Store Medan, mengetahui pengaruh In-Store Display terhadap Impulse Buying pada Labello Store Medan, dan mengetahui pengaruh Price Discount dan In-Store Display terhadap Impulse Buying pada Labello Store Medan. Metodologi penelitian yang digunakan adalah metode deskriptif kuantitatif, unit analisis dalam penelitian ini adalah Labello Store Medan serta unit observasinya adalah pelanggan dari Labello Store Medan sebanyak 980 responden. Teknik penentuan jumlah sampel yang digunakan dalam penelitian ini adalah rumus slovin dan berjumlah sebanyak 91 responden. Metode penelitian yang digunakan yakni dengan teknik pengumpulan data melalui penelitian kepustakaan dan penelitian lapangan yang dilakukan secara sistematik berdasarkan tujuan penelitian. Metode analisis yang digunakan untuk memecahkan permasalahan dan membuktikan hipotesis adalah dengan analisis deskriptif, analisis regresi. Hasil uji koefisien determinasi (R2) menunjukkan bahwa variabel Impulse Buying dipengaruhi oleh variabel Price Discount dan In-Store Display, sedangkan sisanya sebesar dijelaskan oleh pengaruh faktor lain atau variabel lain di luar model, seperti fashion involvement, positive emotion, store image dan media sosial.
\end{abstract}

Kata Kunci : Price Discount, In-Store Display, Impulse Buying

\section{PENDAHULUAN}

Dilihat dari semakin banyaknya konsumen yang mengikuti tren fashion yang selalu berkembang setiap saat, mengakibatkan persaingan bisnis dibidang fashion semakin ketat. Kebanyakan pelaku bisnis berlomba-lomba untuk membuka peluang usaha berupa penjualan fashion. Fashion dalam pembahasan ini bukan hanya sekedar gaya dalam berpakaian tetapi juga ada aksesoris, make up, dan tas. Sebagai pelaku bisnis, untuk bisa memenangkan persaingan bisnis dibutuhkan berbagai pemahaman tentang perilaku konsumen yang terus berubah. Utamanya, 
perusahaan harus bisa membuat daya tarik untuk meningkatkan minat konsumen dalam membeli. Pembelian konsumen jika dilihat dari segi perencanaan, dikategorikan menjadi pembelian terencana dan pembelian tidak terencana. Fenomena yang banyak terjadi sekarang ini adalah konsumen yang awalnya hanya berniat untuk menemani teman atau keluarga berkeliling dan melihat-lihat produk yang dipajang di sebuah toko fashion, tanpa sengaja melihat ada produk yang menarik hati sehingga konsumen secara spontan membelinya. Adapun konsumen yang hanya ingin membeli produk tertentu, tetapi ketika menuju produk tersebut konsumen melewati beberapa pajangan produk yang mencolok sehingga tertarik untuk membelinya, baik karena potongan harga ataupun karena teringat untuk membeli produk tersebut.

Price Discount atau potongan harga merupakan pengurangan harga dari daftar harga yang telah ditetapkan oleh pelaku bisnis dalam periode tertentu. Dalam menetapkan potongan harga, pastinya pelaku bisnis telah mempunyai strategi agar potongan harga yang diberikan tidak menimbulkan kerugian dan dapat menarik pengunjung, baik yang sedang berbelanja maupun yang hanya melintas. In-Store Display atau penataan produk merupakan kegiatan penataan produk dalam ruangan dengan tujuan mempengaruhi calon konsumen untuk membeli produk yang dijual. Penataan produk harus diperhatikan, mulai dari penataan berdasarkan jenis, warna, merek dan dengan letak yang strategis, agar menimbulkan keinginan calon konsumen untuk membeli. Impulse Buying atau pembelian tidak terencana merupakan keputusan untuk membeli produk tanpa perencanaan terlebih dahulu atau terjadi tiba-tiba. Untuk meningkatkan pembelian yang tidak terencana maka diperlukan strategi yang tepat, salah satunya adalah dengan memberikan potongan harga pada produk dan diberikan penanda yang mencolok. Selain itu, perlu dilakukan pemajangan produk yang mudah dilihat dan dijangkau oleh calon konsumen.

\section{KAJIAN LITERATUR}

Menurut Utami (2010:67), pembelian impulsif (Impulse Buying) adalah pembelian yang terjadi ketika konsumen melihat produk atau merek tertentu, kemudian konsumen menjadi tertarik untuk mendapatkannya, biasanya karena adanya rangsangan yang menarik dari toko tersebut, dan menurut Utami (2010:69), ada 4 indikator Impulse Buying antara lain: 1) Spontanity (spontanitas), 2) Power, compulsion, and intensity (kekuatan, kompulsi, dan intensitas), 3) Excitement and simulation (kegairahan dan simulasi) 4) Disregard for consequences (ketidakpedulian akan akibat). Menurut Sutisna (2012:300) Price Discount adalah pengurangan harga produk dari harga normal dalam periode tertentu, dan menurut Sutisna (2012:302), ada 3 indikator Price Discount, antara lain: 1) Besarnya potongan harga, 2) Masa potongan harga, 3) Jenis produk yang mendapatkan potongan harga.

Menurut Stanton (2011:189), In-Store Display adalah usaha mendorong perhatian dan minat konsumen pada toko atau mendorong keinginan membeli melalui daya tarik penglihatan langsung, dan menurut Stanton (2011:190), ada 3 indikator In-Store Display, antara lain: 1) Product Supplying (Pengadaan Barang), 2) Product Grouping (Pengelompokan Barang), 3) Product Arranging (Penyusunan Barang).

Berikut pengujian hipotesis penelitiannya:

H1: Terdapat pengaruh positif dan signifikan Price Discount terhadap Impulse Buying H2: Terdapat pengaruh positif dan signifikan In-Store Display terhadap Impulse Buying 
H3: Terdapat pengaruh positif dan signifikan Price Discount dan In-Store Display terhadap Impulse Buying

Kerangka teoritis dalam penelitian ini akan menjelaskan hubungan antara masing-masing variabel dapat dilihat pada Gambar 1.

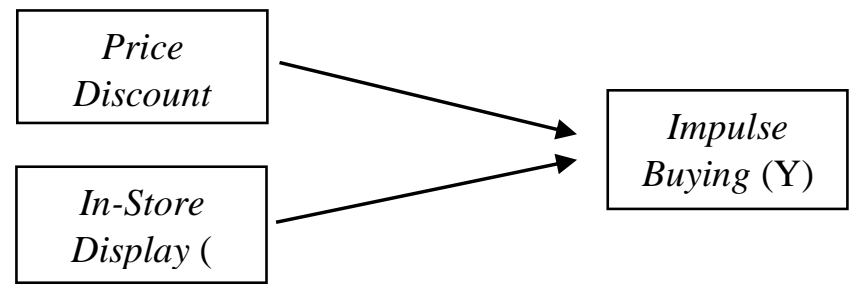

Gambar 1. Kerangka Pemikiran

\section{METODE PENELITIAN}

\section{Lokasi Penelitian}

Penelitian ini dilakukan pada Labello Store yang beralamat di Jl. A.R.Hakim No. 25B, Medan.

\section{Populasi dan Sampel}

Populasi dalam penelitian ini adalah semua konsumen yang melakukan transaksi pembelian di dalam toko. Jumlah populasi adalah 980 orang per tahun 2018.

Teknik pengambilan sampel penelitian ini menggunakan rumus Slovin. Sehingga sampel penelitian ini sebanyak 91 responden.

\section{Teknik Pengumpulan Data}

Metode pengumpulan data yang digunakan dalam penelitian ini adalah metode angket (kuesioner terstruktur) yang diberikan kepada responden, yaitu pelanggan pada Labello Store. Yang dilakukan peneliti untuk mendapatkan data yaitu dengan cara penyebaran angket. Metode angket menurut Sugiyono (2018:142) merupakan teknik pengumpulan data yang dilakukan dengan cara memberi seperangkat pertanyaan atau pernyataan tertulis kepada responden untuk menjawabnya.

\section{Teknik Analisis Data}

Dalam penelitian ini, teknik analisis regresi linier berganda digunakan. Analisis regresi linear berkaitan dengan studi mengenai ketergantungan variabel dependen (terikat) dengan variabel independen (bebas), dengan tujuan untuk mengestimasi dan memprediksi rata-rata populasi atau nilai rata-rata variabel dependen berdasarkan nilai independen yang diketahui. Analisis linear berganda digunakan untuk mengetahui pengaruh Price Discount (X1) dan In-Store Display (X2) terhadap Impulse Buying (Y). Perhitungan dapat dirumuskan dengan formula sebagai berikut:

$\mathbf{Y}=\boldsymbol{\alpha}+\boldsymbol{\beta}_{1} \mathbf{X}_{1}+\boldsymbol{\beta}_{2} \mathbf{X}_{2}+\mathbf{e}$

Keterangan:

$\mathrm{Y}=\quad=\quad$ Impulse Buying (Dependent Variable) 


$$
\begin{array}{llll}
\mathrm{X}_{1} & = & \text { Price Discount (Independent Variable) } \\
\mathrm{X}_{2} & = & \text { In-Store Display (Independent Variable) } \\
\alpha & = & \text { Konstanta } \\
\beta_{1} & = & \text { Koefisien untuk variabel Price Discount } \\
\beta_{2} & = & \text { Koefisien untuk variabel In-Store Display } \\
\mathrm{e} & = & \text { Standard Error }(5 \%)
\end{array}
$$

\section{HASIL DAN PEMBAHASAN}

Karakteristik responden berdasarkan jenis kelamin yaitu responden laki-laki berjumlah 28 orang $(30,8 \%)$ dan responden Perempuan berjumlah 63 orang $(69,2 \%)$. Hal ini dapat disimpulkan bahwa secara keseluruhan responden perempuan lebih mendominasi daripada responden laki-laki. Karakteristik responden berdasarkan usia yaitu responden berusia $<21$ tahun berjumlah 37 orang (40,7\%), responden berusia 21-30 tahun berjumlah 32 orang $(35,2 \%)$ dan responden berusia 31-40 tahun berjumlah 22 orang $(24,2 \%)$. Hal ini menjelaskan bahwa secara kesluruhan usia responden adalah 2130 tahun karena memiliki persentase yang lebih tinggi.

\section{Uji Validitas dan Uji Reabilitas}

Menurut Ghozali (2018), mengukur validitas dapat dilakukan dengan cara melakukan korelasi antar skor butir pertanyaan dengan total skor konstruk atau variabel. Penggunaan item-item sebagai indikator-indikator dari data variable penelitian

\begin{tabular}{|c|c|c|c|}
\hline No & Pernyataan & Variabel & $\mathrm{r}_{\text {hitung }}$ \\
\hline 1 & PD-1 & & 0,742 \\
\hline 2 & PD-2 & Price & 0,812 \\
\hline 3 & PD-3 & Discount & 0,746 \\
\hline 4 & PD-4 & & 0,853 \\
\hline 1 & ISD-1 & & 0,813 \\
\hline 2 & ISD-2 & In-Store & 0,531 \\
\hline 3 & ISD-3 & Display & 0,685 \\
\hline 4 & ISD-4 & & 0,828 \\
\hline 5 & ISD-5 & & 0,806 \\
\hline 1 & IB-1 & & 0,805 \\
\hline 2 & IB-2 & & 0,593 \\
\hline 3 & IB-3 & & 0,670 \\
\hline 4 & IB-4 & Impulse & 0,787 \\
\hline 5 & IB-5 & Buying & 0,749 \\
\hline
\end{tabular}
mensyaratkan adanya suatu pengujian konsistensi melalui uji reliabilitas, sehingga data yang digunakan tersebut benar-benar dapat dipercaya atau memenuhi aspek kehandalan untuk dianalisis lebih lanjut.

Hasil uji Validitas dan Reliabilitas akan disajikan pada tabel 1 dan tabel 2.

Table 2. Descriptive Statistics 


\begin{tabular}{lll}
6 & IB-6 & 0,429 \\
7 & IB-7 & 0,683 \\
8 & IB-8 & 0,816 \\
\hline
\end{tabular}

Dari tabel 1 diperoleh nilai $\mathrm{r}$ hitung dari masing-masing item pernyataan untuk setiap variable diperoleh di atas 0,361 sehingga dapat dikatakan pernyataan yang digunakan dalam variabel penelitian dikatakan validitas.

Tabel 2. Hasil Uji Reliabilitas

\begin{tabular}{llcc}
\hline No & Variabel & $\begin{array}{c}\text { Jumlah } \\
\text { Item }\end{array}$ & $\begin{array}{c}\text { Cronbach's } \\
\text { Alpha }\end{array}$ \\
\hline 1 & $\begin{array}{l}\text { Price } \\
\text { Discount }\end{array}$ & 4 & 0,788 \\
\hline 2 & $\begin{array}{l}\text { In-Store } \\
\text { Display }\end{array}$ & 5 & 0,792 \\
\hline 3 & $\begin{array}{l}\text { Impulse } \\
\text { Buying }\end{array}$ & 8 & 0,847 \\
\hline
\end{tabular}

Dari tabel 2 juga diperoleh dari masing-masing variabel di Cronbach's Alpha tidak dibawah 0,6 sehingga dapat dinyatakan reliable. distribusi kumulatif dari distribusi normal.

\section{Uji Asumsi Klasik}

\section{Uji Normalitas}

Uji normalitas bertujuan untuk menguji apakah dalam model regresi variabel pengganggu atau residual memiliki distribusi normal. Ada dua cara untuk mendeteksi apakah residual berdistribusi normal atau tidak, yaitu dengan analisis grafik dan uji statistik.

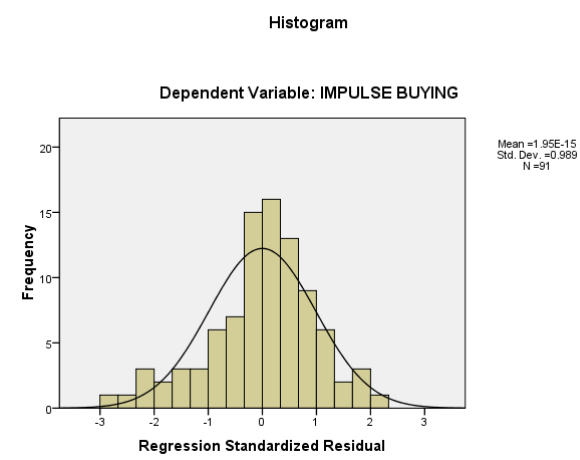

Gambar 2. Grafik Histogram 
Dari Gambar 2 dapat dilihat bahwa data menyebar garis diagonal dan mengikuti arah garis diagonal menunjukkan pola distribusi normal, maka model regresi dianggap memenuhi asumsi normalitas.

Normal P-P Plot of Regression Standardized

Dependent Variable: IMPULSE BUYING

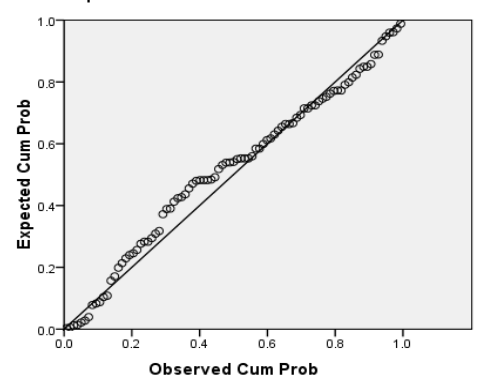

Gambar 3 Grafik Normal P-Plot

Dari Gambar 3 menunjukkan bahwa data (titik) menyebar di sekitar garis normal dan mengikuti arah garis diagonal atau grafik Normal Probabilty Plot menunjukkan pola distribusi normal.

Tabel 3. Uji Statistik Untuk Normalitas

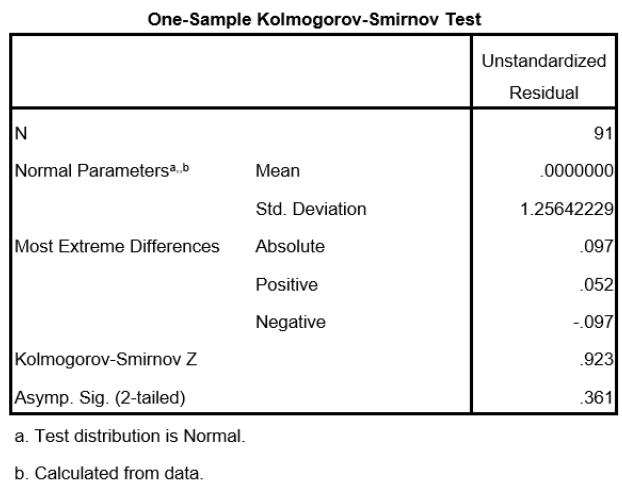

Berdasarkan tabel 3 di atas, maka dapat diketahui nilai signifikan lebih besar dari 0,05 yaitu sebesar 0,361 . Hasil pengujian ini menunjukkan bahwa data berdistribusi normal. 


\section{Uji Multikolinearitas}

Tabel 4. Uji Multikolinearitas

\begin{tabular}{|c|c|c|c|}
\hline \multicolumn{4}{|c|}{ Coefficients $^{a}$} \\
\hline \multirow{2}{*}{\multicolumn{2}{|c|}{ Model }} & \multicolumn{2}{|c|}{ Collinearity Statistics } \\
\hline & & Tolerance & VIF \\
\hline \multirow[t]{3}{*}{1} & (Constant) & & \\
\hline & PRICE DISCOUNT & .823 & 1.215 \\
\hline & IN-STORE DISPLAY & .823 & 1.215 \\
\hline
\end{tabular}

Dari tabel 4 diketahui nilai Tolerance yang diperoleh adalah 0,823 yang lebih dari 0,10 dan nilai VIF yang diperoleh adalah 1,215 yang kurang dari 10 , sehingga dapat dinyatakan tidak terjadi persoalan multikolinieritas dengan varibel bebas lainnya.

\section{Uji Heteroskedastisitas}

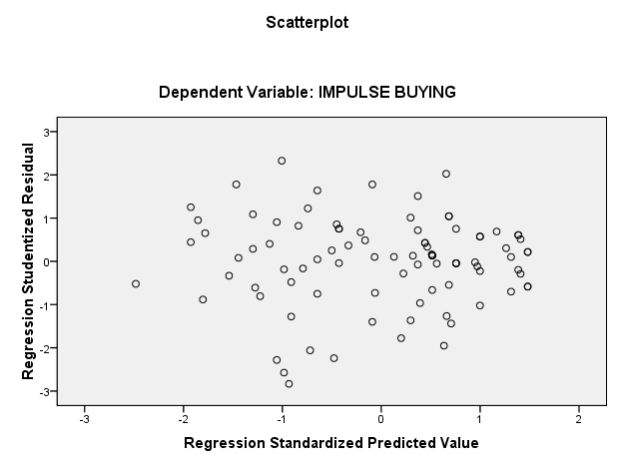

Gambar 4. Grafik Scatterplot

Berdasarkan Gambar 4 terlihat titik-titik secara acak atau tidak membentuk suatu pola tertentu yang jelas secara tersebar baik di atas maupun di bawah angka 0 pada sumbu Regression Studentized Residual (Y). Hal ini berarti tidak terjadi heteroskedasitas pada model regresi sehingga model regresi ini layak digunakan untuk memprediksi Impulse Buying.

\section{Hasil Analisis Regresi Linear Berganda}

Tabel 5. Standardized Coefficients

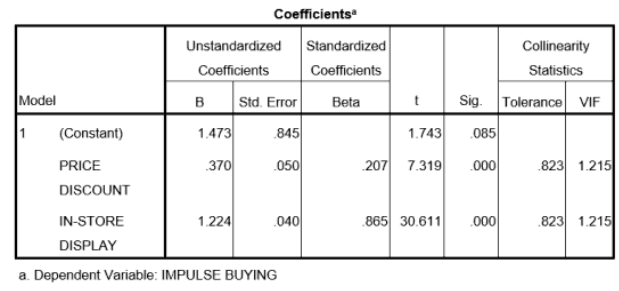


Dari tabel 5, uji regresi linear berganda diperoleh persamaan regresinya adalah:

\section{Impulse Buying = 1,473 + 0,370 Price Discount + 1,224 In-Store Display+ e}

Penjelasan persamaan sebagai berikut:

1. 1,473 artinya: jika Impulse Buying yang diteliti konstan, maka Impulse Buying pada Labello Store adalah sebesar 1,473.

2. 0,370 menunjukkan bahwa Price Discount berpengaruh positif terhadap meningkatnya Impulse Buying sebesar 0,370, sehingga setiap ada peningkatan Price Discount satu satuan, maka Impulse Buying akan meningkat sebesar 0,370.

3. 1,224 menunjukkan bahwa In-Store Display berpengaruh positif terhadap meningkatnya Impulse Buying sebesar 1,224, sehingga setiap ada peningkatan InStore Display satu satuan, maka Impulse Buying akan meningkat sebesar 1,224.

\section{SIMPULAN DAN REKOMENDASI}

Kesimpulan dalam penelitian ini adalah:

1. Hasil penelitian ini menyatakan pengaruh Price Discount (X1) dan In-Store Display (X2) terhadap Impulse Buying (Y) ditunjukkan dari hasil analisis regresi linear berganda Impulse Buying $=1,473+0,370$ Price Discount + 1,224 In-Store Display+ e. Hal ini memberikan arti bahwa variabel Price Discount dan In-Store Display secara bersama-sama mempunyai pengaruh yang positif terhadap Impulse Buying.

2. Hasil Uji t menunjukkan bahwa Price Discount secara parsial memiliki pengaruh positif dan signifikan terhadap Impulse Buying pada Labello Store karena nilai thitung sebesar 7,319 lebih besar dari nilai ttabel yang sebesar 1,986 .

3. Hasil Uji t menunjukkan bahwa In-Store Display secara parsial memiliki pengaruh positif dan signifikan terhadap Impulse Buying pada Labello Store karena nilai thitung sebesar 30,611 lebih besar dari nilai ttabel yang sebesar 1,986 .

4. Hasil Uji F menunjukkan bahwa Price Discount dan In-Store Display secara serempak berpengaruh terhadap Impulse Buying pada Labello Store karena nilai Fhitung sebesar 716,497 lebih besar dari Ftabel yang sebesar 3,10.

5. Hasil uji koefisien determinasi (R2) menunjukkan bahwa nilai R Square yang diperoleh adalah 0,942 yang berarti 94,20\% variabel Impulse Buying dipengaruhi oleh variabel Price Discount dan In-Store Display, sedangkan sisanya sebesar 5,80\% dipengaruhi oleh variabel-variabel lainnya yang tidak diteliti dalam penelitian ini. 


\section{DAFTAR PUSTAKA}

A.C. Nielsen. 2010. Survei of Consumer Behaviour and Perception Toward Modern Retail and Traditional Trade Channels. Jakarta: Departemen Perdagangan Indonesia.

Alma, Buchari. 2014. Manajemen Pemasaran dan Pemasaran Jasa. Bandung:Alfabeta.

Assauri, Sofjan. 2009. Manajemen Pemasaran Konsep Dasar dan Strategi. Jakarta: Rajawali Pers.

Clow, K., Baack, D. 2010. Integrated Advertising, Promotion, and Marketing Communication. New Jersey: Prentice Hall.

Engel, J.F., Blackwell, R.D., Miniard, P.W. 2017. Perilaku Konsumen. Jakarta:Binarupa Aksara.

Gani, Irwan. dan Siti Amalia. 2015. Alat Analisis Data; Aplikasi Statistik untuk Penelitian Bidang Ekonomi dan Sosial. Yogyakarta: Andi.

Kotler, P., dan Keller, K.L.2009. Manajemen Pemasaran. Jilid 1. Edisi 13.Jakarta: Erlangga.

Lisda Rahmawati. 2010. Menciptakan Impulse Buying. Majalah Ilmiah Informatika. Vol.1, No. 3.

McCarthy dan Cannon. 2009. Pemasaran Dasar Pendekatan Manajerial Global. Buku 2 Edisi 16. Jakarta: Salemba Empat.

Mowen, J.C., dan Minor, M. 2010. Perilaku Konsumen. Jakarta: Erlangga.

Ngadiman. 2009. Marketing. Jilid 2. Jakarta: Direktorat Pembinaan Sekolah Menengah Kejuruan.

Peter, J.P., dan Olson J.C. 2014. Perilaku Konsumen \& Strategi Pemasaran. Edisi 9. Jakarta: Salemba Empat.

Pramesti, Getut. 2014. Kupas Tuntas Data Penelitian dengan SPSS 22. Jakarta: Elex Media Komputindo.

Setiawan, Budi. 2015. Teknik Praktis Analisis Data Penelitian Sosial dan Bisnis dengan SPSS. Yogyakarta: Andi.

Sopiah dan Syihabudhin. 2009. Manajemen Bisnis Ritel. Edisi 1. Yogyakarta: Andi Offset.

Stanton, W.J. 2011. Prinsip Pemasaran. Jilid 1. Jakarta: Erlangga.

Sugiyono. 2011. Metode Penelitian Kuantitatif, Kualitatif dan R\&D. Bandung:Alfabeta.

Sumarwan, Ujang. 2011. Perilaku Konsumen. Edisi 2. Bogor: Ghalia Indonesia. 
2011. Riset Pemasaran dan Konsumen. Edisi 1. Bogor: IPB Press.

Sutisna. 2012. Perilaku Konsumen dan Komunikasi Pemasaran. Edisi kedua. Bandung: Remaja Rosdakarya.

Utami, C.W. 2010. Manajemen Ritel: Strategi dan Implementasi Operasional Bisnis Ritel Modern di Indonesia. Edisi 2. Jakarta: Salemba Empat. 